\title{
Peran Tokoh Agama dalam Birokrasi Pemerintahan Raja Marakata
}

\author{
Luh Gede Ratna Citramanik*, Ni Ketut Puji Astiti Laksmi \\ Prodi Arkeologi, Fakultas Ilmu Budaya, Unud \\ [citramanik59@gmail.com], [astitilaksmi@yahoo.com] \\ Gianyar, Bali, Indonesia \\ *Corresponding Author
}

\begin{abstract}
In the period of ancient Bali, religious leaders who were generally known to play a role in religious aspects had also an essential role in the government bureaucracy of a king. This was seen in the reign of King Marakata that the inscriptions he issued in 944 Śaka to 962 Śaka. The inscriptions claimed that the existence of royal government positions held by complete religious leaders indicated by their titles and symbols. There were two purposes of this study. The first was to explain the position and role of religious leaders in the bureaucracy of the government of King Marakata. Second, explained about the mutation of positions of religious leaders. The method used in data collection is in the form of observation, interviews, and using library research. The analysis used is a qualitative analysis, comparative analysis, and contextual analysis. The theories used are structural functionalism theory and power relations theory. Based on theanalysis of the contents of King Marakata's inscriptions, the results obtained that the position and the role of religious leaders are interrelated. Religious leadersdomiciled in the holy place and government bureaucracy. Religious leadersact as clergy and officials both as structural officials and functional officials. The mutation of positions of the religious leaders occurred on his act as an official or clergy. Factors that affect mutations of positions are death, resignation, a dismissal, the appointment, a decline or a promotion, and ability.
\end{abstract}

Keywords: religious figures, role, bureaucracy, mutation of positions.

\begin{abstract}
Abstrak
Pada masa Bali Kuno, tokoh agama yang umumnya diketahui berperan dalam aspek keagamaan, juga memiliki peranan penting dalam birokrasi pemerintahan seorang raja. Pada pemerintahan Raja Marakata hal ini terlihat pada prasasti yang beliau keluarkan pada tahun 944 Śaka hingga 962 Śaka dengan adanya jabatan pemerintahan kerajaan yang dijabat oleh tokoh agama lengkap ditunjukkan oleh gelar dan simbolnya. Tujuan penelitian ini adalah pertama, memaparkan hasil penelitian terkait kedudukan dan peran tokoh agama dalam birokrasi pemerintahan Raja Marakata. Kedua, memaparkan mengenai terjadinya mutasi jabatan tokoh agama. Penelitian
\end{abstract}


ini menggunakan metode pengumpulan data berupa observasi, wawancara, dan studi pustaka. Analisis yang digunakan yaitu analisis kualitatif, analisis komparatif, dan analisis kontekstual. Penulis menggunakan pendekatan teori fungsionalisme struktural dan teori relasi kuasa. Berdasarkan analisis terhadap isi prasasti Raja Marakata diperoleh hasil bahwa kedudukan dan peran tokoh agama saling berkaitan. Tokoh agama berkedudukan di tempat suci dan pemerintahan kerajaan. Tokoh agama berperan sebagai rohaniwan dan pejabat baik pejabat struktural maupun pejabat fungsional. Mutasi jabatan tokoh agama terjadi pada jabatan tokoh agama dalam perannya sebagai pejabat maupun rohaniwan. Faktor yang mempengaruhi terjadinya mutasi jabatan adalah kekuasaan raja, kematian, pengunduran diri, pemecatan, pengangkatan, penurunan atau kenaikan jabatan, dan kemampuan.

Kata kunci : tokoh agama, peran, birokrasi, mutasi jabatan.

\section{Latar Belakang}

Tokoh agama secara umum diketahui memiliki peranan penting dan utama dalam aspek keagamaan. Peranan tokoh agama terkait keagamaan diantaranya memimpin upacara agama, memimpin tempat suci keagamaan, dan mengajarkan pendidikan agama kepada masyarakat. Agama yang berkembang pada masa Bali Kuno adalah Hindu dan Buddha, dimana pendeta Hindu/Siwa disebut Sireng Kasewan dan pendeta Buddha disebut Sireng Kasogatan. Tokoh agama atau pendeta Siwa dan Buddha dalam prasasti Bali Kuno disebut dengan Mpungku Sewasogata (Astra, 2008: 16; Setiawan, 2008: 48). Kriteria tokoh agama ditunjukkan melalui gelar yang dimiliki di antaranya Mpungku Sewasogata, Bhiksu, Pitâmaha, Dang Acarya, Dang Upadhyaya serta Mpu/Mpungku. Penggunaan kata karuhun, makādi, dan sira untuk mengantar penyebutan nama tokoh agama serta penggunaan nama Sanskerta (Astra, 2008: 16-20; Laksmi, 2017: 161-163).

Masa Bali Kuno pada pemerintahan Raja Sri Kesari Warmadewa hingga Paduka Bhatara Sri Astasura Ratnabumibanten yaitu abad X-XV (Ardika, dkk, 2013: 110-129), tokoh agama yang umumnya berperan dalam bidang keagamaan, juga memiliki peran dalam kepemerintahan. Kehadiran tokoh agama dalam pemerintahan seorang raja dianggap penting dan diyakini dapat memperkuat kepemimpinan raja (Bagus, 1993: 146; Astra, 2008: 23-25). Tokoh agama sebagai pejabat pemerintahan baik tingkat pusat maupun daerah menunjukkan bahwa tokoh agama tidak selalu golongan Brahmana saja tetapi juga termasuk golongan Ksatria, sehingga memiliki peran sebagai ulama atau rohaniwan dan pejabat.

Peran tokoh agama dalam berbagai bidang juga termuat dalam prasastiprasasti dari Raja Marakata. Raja Marakata yang bergelar Paduka Haji Sri Dharmawangsawardhana Marakatapangkajasthanottunggadewa adalah keturunan Warmadewa meskipun tidak menggunakan unsur Warmadewa dalam namanya. Bukti ini ditunjukkan dalam Prasasti Tengkulak A yang menyebutkan bahwa Raja Marakata adalah putra dari Raja Sri Dharmodayana Warmadewa (Ardika, dkk, 2013: 120; Laksmi, 2017: 158). Penggunaan nama Dharmawangsa dan Uttunggadewa pada gelar Raja Marakata, menurut Goris menunjukkan bahwa kedudukan beliau 
dari pihak ibu lebih tinggi (Budiastra, 1969: 49-50).

Raja Marakata sebagai Raja Bali Kuno belum banyak dikenal oleh masyarakat, tidak seperti ketenaran Raja Udayana yang merupakan ayah beliau dan Raja Airlangga dan Raja Anak Wungsu yaitu dua saudara beliau. Rajaraja tersebut sudah banyak dibahas sedangkan mengenai Raja Marakata masih kurang. Kurangnya penelitian yang mengungkap tentang Raja Marakata menjadikan seakan-akan Raja Marakata terlupakan dibanding Raja Bali Kuno lainnya, sehingga penulis berkeinginan untuk melengkapi informasi mengenai Raja Marakata. Selain itu, peran tokoh agama pada birokrasi pemerintahan Raja Marakata juga menarik untuk dibahas.

Prasasti Batuan menyebutkan tokoh agama Bhiksu Widya sebagai hulu kayu, Bhiksu Sukaji sebagai rama kabayan, Dang Ācāryya Tiksena sebagai Mpungkwing Udayalaya, Dang Ācāryya Ica sebagai samgat juru wadwa, Dang Ācāryya Bakra sebagai samgat makarun, $\mathrm{Pu}$ Gupit sebagai samgat nayakan asba, dan Bhiksu Bhasya sebagai Mpungku ring Crinatha (Laksmi, 2017: 83-87). Isi Prasasti Batuan tersebut telah mencerminkan bahwa tokoh agama yang disebutkan lengkap dengan gelarnya tidak hanya memiliki peran sebagai rohaniwan yang berurusan dengan keagamaan saja tetapi juga berperan sebagai hulu kayu (pengawas hutan), rama kabayan (pejabat keagamaan), samgat (memberi keputusan), dan samgat nayakan asba (terkait pemeliharaan kuda) yang erat kaitannya dengan jabatan pemerintah dan elite politik.

Mengenai peran tokoh agama dalam birokrasi pemerintahan Raja Marakata belum pernah diungkapkan secara khusus. Meskipun ada, hal tersebut dibahas secara umum berdasarkan beberapa periode pemerintahan raja-raja Bali Kuno. Adapun penelitian sebelumnya membahas peran tokoh agama dalam birokrasi pemerintahan di antaranya Budiastra (1969) memaparkan jabatan-jabatan penting pada pemerintahan Raja Marakata beserta pejabat yang menjabat tanpa penjelasan lebih lanjut. Mahendra (1984) memaparkan kedudukan dan peran tokoh agama tidak hanya di bidang agama, tetapi juga bidang politik, ekonomi, dan sosial budaya dari pemerintahan Raja sebelum Ugrasena hingga Raja Marakata secara umum.

Perbedaan dengan penelitian sebelumnya adalah penelitian ini secara khusus mengungkap mengenai peran tokoh agama dalam birokrasi pemerintahan Raja Marakata dimana tokoh agama tidak hanya berperan sebagai rohaniwan tetapi juga sebagai pejabat pemerintahan yang dibedakan menjadi pejabat struktural dan fungsional. Peran tokoh agama dalam birokrasi pemerintahan yang tidak terlepas dari mutasi jabatan belum pernah dibahas secara mendetail dalam penelitian sebelumnya sehingga penelitian ini penting untuk dilanjutkan.

\section{Pokok Permasalahan}

a. Bagaimana kedudukan dan peran tokoh agama dalam birokrasi pemerintahan Raja Marakata?

b. Mengapa terjadi mutasi jabatan tokoh agama dalam birokrasi pemerintahan Raja Marakata?

\section{Tujuan Penelitian}

a. Untuk mengetahui kedudukan dan peran tokoh agama dalam birokrasi pemerintahan Raja Marakata

b. Menjawab permasalahan mengenai mutasi jabatan tokoh agama dalam birokrasi pemerintahan Raja Marakata.

\section{Metode Penelitian}

Dalam menjawab rumusan masalah yang telah disusun sebelumnya, penulis 
menggunakan teori dan analisis data guna memperoleh hasil yang relevan dari penelitian yang dilakukan. Penelitian ini menggunakan teori fungsionalisme struktural dimana dalam sebuah sistem sosial seperti halnya struktur birokrasi yang terdiri atas jabatan-jabatan yang saling berhubungan satu sama lain meskipun memiliki kedudukan dan fungsinya masing-masing.

Teori relasi kuasa menyatakan bahwa kekuasaan tidak hanya sekedar menguasai dan dikuasai tetapi mengenai tindakan untuk mengendalikan dan mengarahkan perilaku orang lain.

Kedua teori tersebut kemudian dikombinasikan dengan analisis kualitatif, analisis komparatif, dan analisis kontekstual untuk memperoleh hasil. Analisis kualitatif dilakukan terhadap data kualitatif dan disajikan dalam bentuk deskriptif. Analisis komparatif dilakukan dengan membandingkan sisi prasasti Raja Marakata dengan Raja sebelumnya yaitu Raja Udayana. Analisis kontekstual dilakukan untuk memperoleh kaitan antara peran tokoh agama dengan isi prasasti.

\section{Hasil Dan Pembahasan}

\subsection{Gambaran Umum Pemerintahan Raja Marakata}

Prasasti Raja Marakata diantaranya sebagai berikut: Prasasti Batuan (944 Śaka/1022 Masehi), Prasasti Tengkulak A (945 Śaka/1023 Masehi), Prasasti Sawan I: Bila I (945 Śaka/1023 Masehi), Prasasti Buwahan B (947 Śaka/1025 Masehi), Prasasti Ujung (962 Śaka/1040 Masehi), Prasasti Kesian Pura Sibi I (945 Śaka/1023 Masehi), Prasasti Kesian Pura Sibi II (948 Śaka/1026 Masehi), Prasasti Kesian Pura Sibi III (948 Śaka/1026 Masehi), Prasasti Kesian Pura Sibi IV, dan Prasasti Bangli Pura Kehen B tanpa angka tahun (Goris, 1954: 351-357; Bagus, 1993: 118-120).
Raja Marakata adalah raja Bali Kuno yang memerintah pada tahun 944 Śaka/1022 Masehi sampai 962 Śaka/1040 Masehi. Beliau memerintah setelah Śri Sang Ajñadewi yang merupakan seorang ratu dengan pemerintahan yang berlangsung tahun 938 Śaka (Budiastra, 1969: 43). Rentang waktu pemerintahan beliau ditetapkan berdasarkan prasati yang menyebut nama beliau dengan angka tahun paling muda dan paling tua.

Berdasarkan isi prasasti tersebut, diketahui bahwa susunan birokrasi pemerinatahan Raja Marakata terdiri dari raja, senapati, samgat, mpungku sewasogata, nayakan, caksu, hulu, manuratang, adhi karana, rggap parlpahan, pituha, bsar, parawuluwulu, madudri dan rama kabayan.

Masyarakat pada pemerintahan Raja Marakata, menganut agama Siwa dan Buddha dengan adanya penyebutan tokoh-tokoh agama Dang Ācāryya (Siwa) dan Dang Upadhyaya (Buddha). Kegiatan perekonomian masyarakat terlihat dari adanya kegiatan jual beli, penggunaan mata uang, pembudidayaan hewan ternak, dan pemanfaatan sawah. Raja Marakata juga melakukan penegakan hukum, peraturan dalam bermasyarakat, peraturan terhadap harta warisan, dan kesenian.

\subsection{Kedudukan dan Peran Tokoh Agama dalam Birokrasi Pemerintahan Raja Marakata}

Tokoh agama diidentifikasi melalui gelar dan simbol yang dimiliki. Gelar yang menunjukkan tokoh agama pada masa Raja Marakata yaitu Bhiksu, Pu/Mpu, Dang Ácāryya, dan Dangupadhyaya. Ungkapan honorifik yang bermakna penghormatan yaitu karuhun (didahulukan), makādi (terutama), dan sira (beliau).

Pada pemerintahan Raja Marakata, tokoh agama ada yang berkedudukan di tempat suci dan pemerintahan kerajaan. Peran sangat berkaitan dengan 
kedudukan yang dimiliki oleh seseorang. Kedudukan akan diperoleh dengan melakukan peran penting dan sangat dihargai oleh masyarakat (Koentjaraningrat, 2009: 139; Sutinah dan Norma, 2004: 157-158).

Berdasarkan kedudukannya di tempat suci, tokoh agama pada pemerintahan Raja Marakata berperan sebagai rohaniwan. Tokoh agama yang memimpin tempat suci diketahui melalui pengantar mpungkwing (pendetaku di) sebelum penyebutan nama nama tokoh agama (Astra, 2008: 16-20; Laksmi, 2017: 161-163). Tempat suci yang disebutkan dalam prasasti Raja Marakata diantaranya Udhayalaya, Antakunjarapada, Banu Tiga, Hyang Padang, Pasaban, Lokeśwara, Srinatha, Kutihanar, Bajrasikhara, Dewasamuha, Amarawati, dan Dharmaryya.

Peran tokoh agama sebagai rohaniwan di tempat suci adalah bertanggung jawab sepenuhnya atas upacara yang dilangsungkan di sana. Tokoh agama menjadi orang yang menghaturkan upacara. Upacara itu meliputi upacara caru dan upacara yang dilaksanakan secara rutin di tempat suci. Bukti adanya upacara yang dilaksanakan pada masa Raja Marakata, termuat dalam Prasasti Batuan yaitu IIIb. 6. “...pasanga $i$ pakrisan ..." yang artinya: IIIb. 6 . '...upacara bulan kesembilan di Pakerisan ...' Tokoh agama bertanggung jawab menghaturkan persembahan penduduk kepada Bhatara berupa sesaji. Sesaji yang diperembahkan salah satunya dalam bentuk banten seperti yang diebutkan Prasasti Sawan I= Bila I yaitu mahābantěn (Wardi, 1986: 111-112). Tokoh agama juga berperan dalam menjaga kesucian bangunan suci.

Peran tokoh agama sebagai pejabat dibedakan atas pejabat struktural dan pejabat fungsional. Tokoh agama sebagai pejabat struktural secara tegas tercantum dalam struktur birokrasi pemerintahan. Jabatan struktural yang dimaksud adalah jabatan senapati, samgat, hulu kayu, dan rama kabayan. Peran tokoh agama pun menyesuaikan dengan jabatan yang dimiliki.

Senapati berperan dalam urusan pemerintah mengenai hukum dan penegakan keadilan. Samgat berperan sebagai pemegang keputusan terhadap suatu hal yang menjadi keahliannya. Hulu kayu dan rama kabayan adalah pemuka desa yang menampung aspirasi penduduk. Hulu kayu berperan dalam hal kepengurusan hutan. Rama kabayan berperan dalam memimpin desa.

Pejabat fungsional tidak tercantum dalam struktur birokrasi pemerintahan tapi kehadirannya penting guna kelancaran kegiatan pemerintahan. Pejabat fungsional ini dibedakan menjadi pengajar, saksi persidangan, perantara desa dengan raja, dan pelaku seni.

Memang tidak secara langsung dinyatakan bahwa tokoh agama yang merupakan rohaniwan juga berperan sebagai seorang pendidik, namun dalam beberapa prasasti dari Raja Marakata mengidentifikasikan bahwa tokoh agama yang berkedudukan di tempat suci juga memberi pendidikan. Pada prasasti Sawan I=Bila I menyebutkan IIIb. 4. “...mpungku mahāguru ing śri nātha dangupādhyaya bhasya ..." yang artinya pendetaku guru besar di Srinatha Dangupadhyaya Bhasya. Mahāguru (guru besar) mengandung kata guru yang memiliki arti seorang pengajar yang memberikan pendidikan kepada siswanya (Mahendra, 1984: 69-71; Wardi, 1986: 29).

Prasasti Tengkulak A menyebutkan bahwa tokoh agama yang memanggil penduduk agar tidak keliru dalam menulis sehingga tidak menimbulkan dosa. Pengetahuan agama dan bidang lainnya membuat tokoh agama pantas dijadikan guru dalam ilmu pengetahuan dan susila.

Kehadiran tokoh agama dalam persidangan kerajaan sangat diperlukan 
dalam pengambilan keputusan raja. Pejabat itu adalah para senapati dan samgat yang merupakan pejabat kerajaan tingkat pusat. Beliau berperan dalam menyaksikan penganugrahan prasasti yang isinya penting tidak hanya bagi desa yang dianugrahkan melainkan juga untuk kerajaan (Mahendra, 1984: 54-58; Astra, 1997: 250-255).

Pejabat fungsional sebagai perantara adalah kelompok senapati dan samgat. Para senapati dan samgat pada masa Raja Marakata berperan sebagai perantara antara pemuka desa dengan raja dalam menyampaikan permasalahan yang dialami penduduk. Jabatan senapati sebagai perantara terlihat pada Prasasti Sawan I= Bila I adalah Senapati Tunggalan yang bernama $\mathrm{Pu}$ Gosaya. Jabatan samgat sebagai perantara desa yaitu samgat nayakan asba yang dijabat Pu Gupit pada Prasasti Batuan.

Selanjutnya ada tokoh agama sebagai pelaku seni yang dalam prasasti Raja Marakata yaitu Prasasti Kesian Pura Sibi I dan III. Prasasti tersebut menyebutkan tokoh agama yang berperan dalam pemahat arca (sulpika). Terpenuhinya sarana keagamaan penduduk secara tidak langsung telah menunjukkan pengaruh peran tokoh agama sebagai pemahat arca dalam keberhasilan atas pemerintahan seorang raja.

Berdasarkan hasil wawancara yang penulis lakukan di Desa Buahan, terdapat keberlanjutan jabatan tokoh agama seperti yang telah disebutkan dalam prasasti Raja Marakata yaitu Prasasti Buwahan B. Jabatan itu adalah rama kabayan yang pada masa sekarang dikenal dengan jero kubayan. Jero kubayan berperan dalam pelaksanaan upacara di seluruh pura di Desa Buahan sebagai pemimpin upacara dan sebagai pemucuk desa yang sangat dihormati masyarakat. Keputusan jero kubayan sangat penting bagi masyarakat tidak hanya terkait kegiatan keagamaan namun juga dalam paruman dan pesangkepan desa terkait urusan adat di Desa Buahan. Pemilihannya berdasarkan tegak krama dan harus termasuk dalam krama ngarep. Jero kubayan yang sebelumnya dapat digantikan oleh pejabat dibawahnya yaitu jero bau, kemudian jero singgukan, dan jero saing yang merupakan dulu desa atau saing krama nembelas begitu seterusnya. Alasan pergantiannya adalah cuntaka karena istri meninggal, semua anak sudah menikah, cucu sudah menikah, dan sakit yang tidak terobati.

\subsection{Mutasi Jabatan Tokoh Agama dalam Birokrasi Pemerintahan Raja Marakata}

Kitab Manawa Darmaśastra menyebutkan bahwa pejabat dipilih oleh raja. Pejabat yang ditunjuk oleh raja harus memenuhi integritas, bijaksana, tegas, dan terlatih. Pejabat patut memiliki latar belakang keluarga yang baik, jujur, berani, dan terampil. Raja memilih orang yang dijadikan pejabat dengan berbagai keahlian dalam ilmu pengetahuan (Pudja dan Sudharta, 2003: 368-370).

Raja pada masa Bali Kuno memegang kekuasaan tertinggi menjadikannya memiliki wewenang untuk mengatur pejabat bawahannya termasuk memilih pejabat kerajaan. Pejabat harus memiliki kemampuan dan pengetahuan yang sesuai dengan jabatannya. Pemilihan jabatan akan mempengaruhi berjalannya pemerintahan. Maka dari itu, raja harus bijaksana memilih pejabat yang berilmu pengetahuan tinggi dan memiliki akhlak mulia. Sangat pantas bila raja memilih sebagian besar pejabatnya dari tokoh agama.

Pejabat yang dipilih oleh raja berasal dari orang kepercayaannya (Astra, 1997: 241). Hal tersebut juga diatur dalam kitab Manawa Dharmaśastra yang menyatakan bahwa orang terpercaya yang terpilih sebagai pejabat hendaknya mentaati aturan kitab suci. Tokoh agama harus mendekatkan diri dan menjalin 
hubungan dengan orang terpandang (raja). Raja pun harus tetap menghormati tokoh agama (Pudja dan Sudharta, 2003: 276-384). Berdasarkan hal tersebut, perolehan jabatan oleh tokoh agama sudah tidak disangikan lagi bahwa mereka adalah orang terhormat, terpercaya dan menguasai kitab suci.

Jabatan tokoh agama tidak luput dari mutasi jabatan yang meliputi pergantian, perpindahan, pengangkatan, dan pemberhentian pejabat. Hal ini terjadi pada tokoh agama tokoh agama yang berperan sebagai rohaniwan maupun pejabat. Mutasi jabatan tokoh agama sebagai rohaniwan berkaitan dengan tempat suci, tempat beliau berkedudukan. Tempat suci Udhayalaya memiliki rohaniwan Dang Ācāryya Tiksna dari tahun 944-947 Śaka dan pada Prasasti Bangli Pura Kehen B digantikan oleh Dang Ācāryya Hrdaya. Mutasi jabatan juga terjadi di tempat suci Hyang Padang pada tahun 962 Śaka rohaniwan yang berkedudukan disana adalah Dang Ācāryya Pagreśwara kemudian digantikan oleh Dang Ācāryya Netra.

Tokoh agama sebagai pejabat mengalami mutasi pada beberapa jabatan. Jabatan senapati dinganga pada pemerintahan Raja Marakata pernah dijabat oleh Pu Angharas (945 Śaka) dan $\mathrm{Pu}$ Kandara (947 Śaka). Pu Kandara pernah menjabat sebagai senapati kuturan berdasarkan Prasasti Bangli Pura Kehen B. Senapati tunggalan dari tahun 945-947 Śaka dijabat oleh Pu Gosaya. Kemudian pada Prasasti Bangli Pura Kehen B beliau bermutasi menjadi senapati maniringin. Jabatan Senapati maniringin, juga pernah dijabat oleh $\mathrm{Pu}$ Kahaji pada tahun 945 Śaka.

Senapati danda dijabat oleh $\mathrm{Pu}$ Kakiya (945 Śaka) dan Pu Mangrawas (947 Śaka). Samgat juru wadwa pada tahun 944-945 Śaka dijabat oleh Dang Ācāryya Ica dan pada tahun yang sama digantikan oleh Dang Ācāryya Pisaningu, tahun 947 Śaka digantikan oleh Dang Ācāryya Kesantan dan dalam Prasasti Bangli Pura Kehen B dijabat oleh Dang Ācāryya Kembat.

Pejabat samgat makarun yaitu Dang Ācāryya Bakra menjabat tahun 944 Śaka, Dang Ācāryya Cakra tahun 945 Śaka. Kemudian dgantikan oleh Dang Ācāryya Nikantaka di tahun yang sama, tahun 947 Śaka digantikan oleh Dang Ācāryya Wastra dan yang selanjutnya Dang Ācāryya Kinjalka. Pu Gupit pada tahun 944-945 Śaka menjabat sebagai samgat asba/samgat nayakan asba, digantikan oleh Pu Yukti pada tahun 947 Śaka dan $\mathrm{Pu}$ Gupit mengalami mutasi sebagai senapati pinatih.

Mutasi jabatan yang terjadi terhadap jabatan yang dijabat oleh tokoh agama tersebut dapat disebabkan oleh berbagai faktor. Faktor itu di antaranya kekuasaan raja, pengunduran diri, pemecatan, pengangkatan, dan mengalami penurunan atau kenaikan jabatan. Faktor yang mempengaruhi terjadinya mutasi jabatan kembali lagi kepada syarat perolehan jabatan tokoh agama. Syarat itu adalah kesesuaian kemampuan dengan jabatan yang diberikan oleh raja. Faktor utama penentu mutasi jabatan pada pemerintahan Raja Marakata adalah kekuasaan raja.

\section{Simpulan}

Berdasarkan pembahasan yang telah dipaparkan, diperoleh beberapa simpulan sebagai berikut.

a. Kedudukan dan peran tokoh agama pada pemerintahan Raja Marakata saling berkaitan. Tokoh agama berkedudukan di tempat suci dan pada pemerintahan kerajaan. Peran tokoh agama dalam birokrasi pemerintahan Raja Marakata dibedakan menjadi tokoh agama sebagai rohaniwan dan tokoh agama sebagai pejabat baik struktural maupun fungsional.

b. Mutasi jabatan dipengaruhi oleh kekuasaan raja. Mutasi terjadi pada 
jabatan senapati dinganga, senapati tunggalan, senapati maniringin, senapati kuturan, senapati pinatih, samgat juru wadwa, samgat makarun, dan samgat asba/nayakan asba. Mutasi jabatan tokoh agama sebagai rohaniwan terjadi di Udhayalaya dan Hyang Padang.

\section{Daftar Pustaka}

Ardika, I Wayan. 2013. Sejarah Bali dari Prasejarah hingga Modern. Denpasar: Udayana University Press.

Astra, I Gede Semadi. 1997. "Birokrasi Pemerintahan Bali Kuno Abad XII-XIII: Sebuah Kajian Epigrafis". Disertasi. Universitas Gadjah Mada.

, I Gede Semadi. 2008. "Kedudukan dan Peranan Tokoh Agama dalam Usaha Bina Negara; Bercermin pada Masa Lampau" dalam Pusaka Budaya dan Nilai-nilai Religiusitas. Denpasar: Jurusan Arkeologi Universitas Udayana. 10-29.

Bagus, I Gusti Ngurah. 1993. "Kebudayaan Bali" dalam Manusia dan Kebudayaan di Indonesia. Jakarta: Djambatan. 286-306.

Budiastra, Putu. 1969. "Djaman Pemerintahan Marakata". Skripsi. Fakultas Sastra, Universitas Udayana.

Goris, R. 1954. Prasasti Bali I. Bandung: NV Masa Baru.

Koentjaraningrat. 2009. Pengantar Ilmu Antropologi Edisi Revisi 2009. Jakarta: PT Rineka Cipta.

Laksmi, Ni Ketut Puji Astiti. 2017. "Identitas Keberagamaan Masyarakat Bali Kuno pada Abad IX-XIV Masehi: Kajian Epigrafis". Disertasi. Program Pasca Sarjana, Fakultas Ilmu Pengetahuan Budaya, Universitas Indonesia.
Mahendra, Ida Bagus Weda. 1984. "Kedudukan dan Peran Tokoh Agama pada Abad IX-XI di Bali". Skripsi. Program Studi Arkeologi, Fakultas Sastra, Universitas Udayana.

Pudja, G., Tjokorda Rai Sudharta. 2003. Manawa Dharmaśastra (Manu Dharmaśastra) atau Weda Smrti Compendium Hukum Hindu. Jakarta: CV. Nitra Kencana Buana.

Setiawan, I Ketut. 2008. "Mengamati Aktivitas Keagamaan Masyarakat Bali Kuno Melalui Tinggalan Arkeologi" dalam Pusaka Budaya dan Nilai-nilai Religiusitas. Denpasar: Jurusan Arkeologi Universitas Udayana. 46-58.

Sutinah, Siti Norma. 2004. "Stratifikasi Sosial: Unsur, Sifat, \& Perspektif" dalam Sosiologi: Teks Pengantar dan Terapan. Jakarta: Kencana.151-167.

Wardi, I Nyoman. 1986. "Keagamaan pada Zaman Bali Kuno Abad XIIXIII (Sebuah Kajian Epigrafis)". Skripsi. Jurusan Arkeologi, Fakultas Sastra, Universitas Udayana. 